\title{
Waste to Energy: Management of Biodegradable Healthcare Waste through Anaerobic Digestion
}

\author{
Nimesh Dhakal ${ }^{1}$, Amrit Bahadur Karki² and Mahesh Nakarmi ${ }^{3}$ \\ ${ }^{1}$ Central Department of Environmental Science, Tribhuvan University, Kathmandu, Nepal \\ ${ }^{2}$ Nepal Academy of Science and Technology (NAST), Laltipur, Nepal \\ ${ }^{3}$ Health Care Foundation Nepal, Kathmandu, Nepal \\ e-mail: nimesdhakal@gmail.com
}

\begin{abstract}
This research was carried out in $21 \mathrm{~m}^{3}$ Technology for Economic Development (TED) model biogas plant constructed and operated at Bir Hospital, Kathmandu. The digester was fed with $95 \mathrm{~kg}$ of mixed waste per day in average generated at Bir Hospital. Average biogas production recorded per day was $5.78 \mathrm{~m}^{3}$ which increased to $8.09 \mathrm{~m}^{3}$ per day after the feeding reached 15 tons after five months of regular feeding. The recorded burning time for this volume of gas was 12-14 hours per day in a stove of $0.22 \mathrm{~m}^{3}$. Methane content in the gas reached up to $54 \%$ of the total volume and $\mathrm{pH}$ in the biodigester was maintained in a range of 6-7. The retention time of the biodigester was 147 days and the average energy content of biogas has been found as $4.38 \mathrm{Kwh}_{\mathrm{th}} / \mathrm{m}^{3}$. The payback period of the biodigester installed is 4 years when compared with LPG, since most of the hospitals use LPG as their cooking fuel it was only analyzed with the LPG. The total reduction of the GHGs was found to be 75.8 tons of $\mathrm{CO}_{2}$ equivalents per annum and the total reduction in terms of monetary benefits was 531.18 USD per annum. Except in one case the presence of E.coli was identified, beside its presence none of other harmful pathogens were detected in the slurry obtained.
\end{abstract}

Key words: anaerobic digestion, healthcare waste, sustainable waste management, treatment of healthcare waste

\section{Introduction}

In global context of rising concern over human diseases, climate change, environmental pollution and resource scarcity, there is a compelling need to embrace the beneficial uses of organic waste materials as resources.

Healthcare waste materials are serious health and environmental hazards. Healthcare waste management is poorly addressed despite of knowledge on hazards attached to it. In recent day's management of healthcare waste has become even more challenging due to the growing number of healthcare facilities because of expanded immunization programmes and the increasing number of HIV/AIDS infected people in the country and injecting drug users (Preuss et al. 1999).

WHO defines pathological waste as the waste including body parts, fetus and placenta generated from the health care facilities during the course of providing treatment. (Preuss et al. 1999). Health care waste generation in Kathmandu was 1.7 per bed per day (MoH 2003).

Health care waste treatment and its proper management are global issues with growing challenges especially in case of developing countries such as Nepal. In a country like Nepal where proper healthcare waste management has been a neglected issue, increasing the effective of management of health care waste is one of the greatest challenges.

An endless flow of materials through medical facilities end up in large, diverse and toxic waste stream, much of which is carried away to a municipal dumping site or burned in incinerators throwing those hazardous substances into the air and into the surface of earth. 
This has increased the risk to environment causing potential health hazards to the whole community.

At present, there is no suitable disposal route for the pathological waste, and the hospitals are paying the municipal contractor only for removing the waste from the hospital complex unaware of all the potential hazards that could occur due to the mismanagement of the waste.

The hazardous hospital waste can come into direct or indirect contact with human beings during several stages in the waste cycle like waste generation and storage, waste collection and handling, recycling and reuse, transfer and transportation, treatment and disposal, etc. Disposal of these toxic waste is a major environmental problem, as it when enters the human body via air, water, soil or other sources might lead to illness or sometimes death in the long run.

Improperly treated health care waste into the landfill site or river system along with municipal waste can affect the whole food chain system and water chain system. When the waste gets disposed off in areas nearby groundwater source used for drinking purposes, the whole water body can become chemically and microbiologically polluted. Direct dumping of such untreated hazardous waste in riverbanks or other landfill sites can lead into accumulation of toxic substances in the soil thereby causing soil pollution. This might affect the people who live on it, plants that put roots into it and animals that move over it. Disposal of sewage and radiological waste from hospital into water system can damage aquatic life and spread water-borne infections like cholera, typhoid, jaundice, hepatitis, etc. Similarly the emission of greenhouse gas like methane gas from the landfill of municipal solid waste can also be another problem causing air pollution.

When health care waste is burned openly or in a defective and insufficient incinerator with no emission control device (which is the case with majority of incinerators in developing countries), highly toxic gases like dioxins, furans, heavy metals like mercury, lead, cadmium, zinc, etc., acid gases and other dangerous particulate matters may be produced. The Environmental Protection Agency found that dioxin not only causes cancer, but at even smaller levels, it may lead to birth defect among the women working or living close to landfill, developmental and immune system disorder problems, some acute health effects, serious illness, etc. WHO has established tolerance intake limits for dioxins and furans, but not for emission. The emission limits defined by a number of countries range from $0.1 \mathrm{ng} \mathrm{TEQ} / \mathrm{m}^{3}$ (Toxicity Equivalence) in Europe to $0.1 \mathrm{ng}$ to $5 \mathrm{ng} \mathrm{TEQ} / \mathrm{m}^{3}$ in Japan, according to incinerator capacity. (Preussetal. 1999)

The infectious waste coming from hospital patients is sometimes multiple drugs resistant. Disposal of such waste into the fertile soil may transfer drug resistant characteristic into the normal bacteria. The normal bacteria in turn could become more pathogenic and multiple drug resistant and hence may help in the emergence of new profile of bacteria.

Hence anaerobic digestion Process has the potential to solve both of the aforesaid problems and provide a source of clean fuel as biogas and slurry as compost.

The main objective of this research was to identify and analyze anaerobic digestion process as an alternative for the management of biodegradable healthcare waste. The research focused on energy production, relation between temperature and gas production, payback period analysis and greenhouse gases emissions to further analyze the objective.

Also the research analyzed the slurry for pathogensfree fertilizers in view of establishing this technology as one of the safe and efficient technologies for the management of the biodegradable waste of healthcare facilities.

\section{Methodology Site and size selection}

The study was carried out in Bir hospital, Mahaboudha, Kathmandu. This is the nation's oldest medical institute established in 1889 AD. It has currently 460 beds.

The construction work started in June 21, 2011 under the supervision of Yasodha Sustainable Development Pvt. Ltd. Rastriya Gobar Gas Company (RGG) was assigned for construction based upon the approved TED-biodigester model. The size of the plant was 
decided to be $21 \mathrm{~m}^{3}$ based on the assessment of average generation of biodegradable health care waste in the hospital by Health Care Foundation Nepal (HECAF), a non-profit organization supporting Bir Hospital since 2009 for establishment of safe, environmentally friendly health care waste management system in the hospital.

\section{Insulation and loading of the digester}

The biodigester was covered with old mattresses that were unused in the hospital and Saw dust was added on the top of it before covering with the soil. The plant was initially loaded with cow dung mixed with leftover food waste collected from the hospital wards. After this it was regularly fed with food waste generated from the wards and the kitchen. Nearly after a year of operation of the digester, approximately $5 \mathrm{~kg}$ of amputed pathological waste generated from the hospital operation theater was added in it. The process was continued thereafter.

\section{Recording of the temperature}

Ambient temperature, temperature of the feedstock inside the dome, and temperature of gas inside the dome were recorded using a sensor that was inserted into the biodigester during construction phase. A copper wire was used to insert the sensor with its other end sealed and fixed with the concrete. The temperature sensors were placed at three points; close to the biodigester fixed in the wall for ambient temperature, at the level of the feedstock, and at the top near the gas outlet point.

\section{Recording of the gas composition and volume}

The volume of carbon dioxide and methane in the biogas generated were regularly measured using two different types of gas analyzers, Dragger X-am 7000 and Biogas board 3200 .

\section{Recording of pressure and $\mathbf{p H}$}

Initially, pressure gauze of $10 \mathrm{Kpa}$ was installed at the top of the dome by fitting it in the hollow copper wire installed in the dome. Gradually when the production of the gas increased above $10 \mathrm{Kpa}$, it was replaced with 16 Kpa capacity. Similarly, pH of samples were collected from both the inlets (feedstock) and outlet (slurry) and recorded using Biogas board $3200 \mathrm{pH}$ detector.

\section{Testing of the pathogens}

Mainly pathogenic and hospital acquired infections present in the waste and the slurry were investigated. No other fecal material except cow dung was used in the beginning as starter to inoculate appropriate microorganisms in the digester.

Since no fecal materials were added, pathogens transferred from fecal oral contamination (pathogens in fecal particles from one host were introduced into the oral cavity of another potential host) were not investigated except for selected species such as Ascaris and E.coli as indicator species for the fecal oral contamination.

\section{Sampling for analysis}

Sampling from three different points in the digester was conducted for analysis:

a) the waste in the inlet

b) the slurry from the outlet and

c) the slurry from the end of the outlet chamber

The samples were collected and analyzed twice during the study period only after feeding of the pathological waste, in April and May 2012. Special precautions were taken to prevent the contamination during the sampling process.

\section{Results and Discussion}

Different variables were recorded from $24^{\text {th }}$ August 2011 to $10^{\text {th }}$ September 2012. It took 15 days after feeding the biodigester to produce methane gas. The flow could also be measured only after a month of gas production. The results are presented below:

\section{Cumulative feeding and gas production}

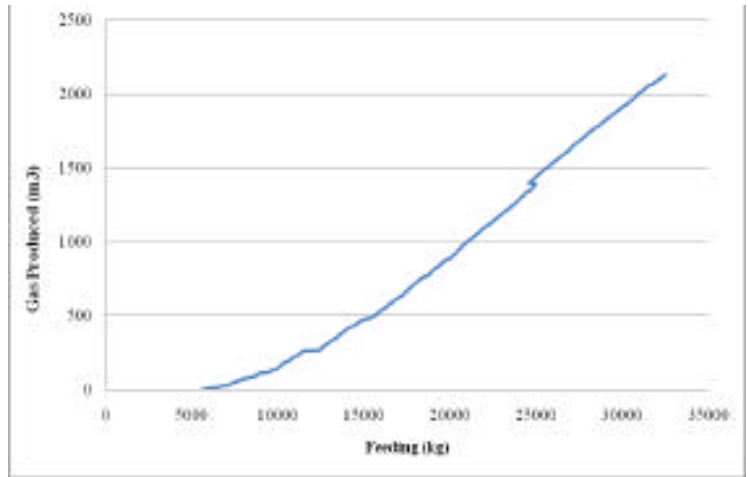

Fig. 1. Cumulative feeding and cumulative gas production 
Figure 1 shows that the production of gas was in accordance with the volume of feedstock fed into the digester. The volume of the gas produced increased with the increase in the amount of feedstock. In the present set-up, on an average $95 \mathrm{~kg} /$ day of the feedstock was fed to the digester which produced 5.775 $\mathrm{m} 3$ of gas per day. The minimum and maximum amount of feedstock used per day was $18.2 \mathrm{~kg}$ (initially) and $158 \mathrm{~kg}$ respectively.

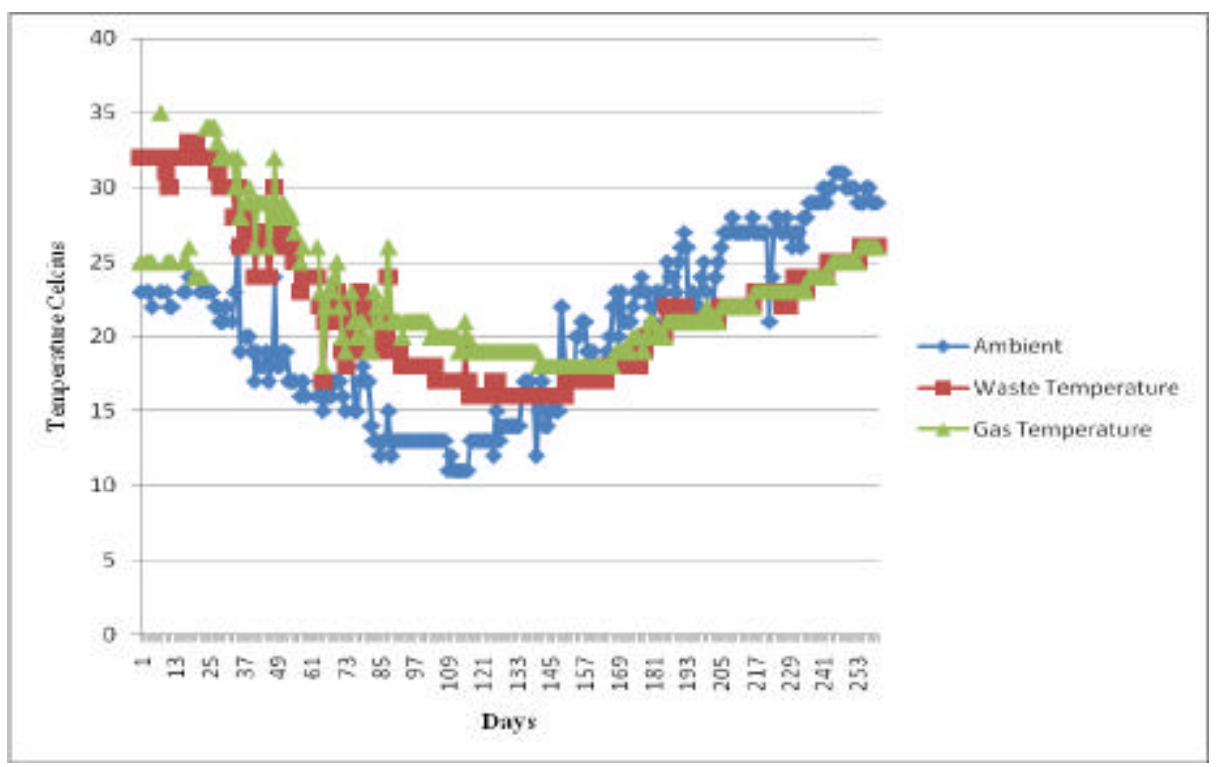

Fig. 2. Figure showing the temperature track

Figure 2 revealed that the temperature inside the biodigester for both the feedstock and the gas was quite stable. Some inconsistencies were observed initially due to technical problem in the temperature sensor itself but the readings were more stable later on. It was observed that the temperature inside the biodigester was directly proportional to the ambient temperature. The minimum ambient temperature recorded throughout the study period was $11^{\circ} \mathrm{C}$ and the temperature of the feedstock and gas inside the

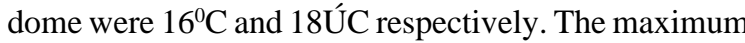
ambient temperature recorded was $32^{\circ} \mathrm{C}$ and the temperature of the feedstock and gas inside the dome were $32^{\circ} \mathrm{C}$ and $35^{\circ} \mathrm{C}$ respectively.

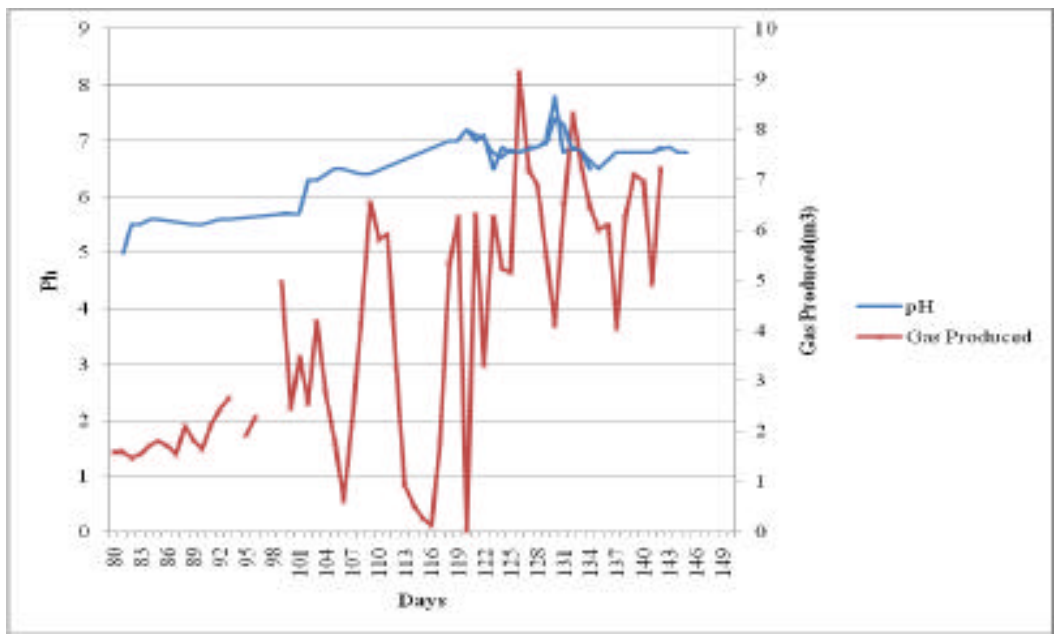

Fig. 3. Graphical analysis of $\mathrm{pH}$ and gas consumed/day 
Figure 3 reveals that initially the $\mathrm{pH}$ was in the range of 5.5 during which the gas production was low too. The acidogenic reaction during the initial phase of biodigestion was the main reason for lower $\mathrm{pH}$ in the digester. As the $\mathrm{pH}$ slowly increased to the range of 6-
7 the gas production also increased gradually. Once the addition of feedstock was consistent, $\mathrm{pH}$ remained stable around 7 which resulted in increased gas production.

\section{Feeding and retention time}

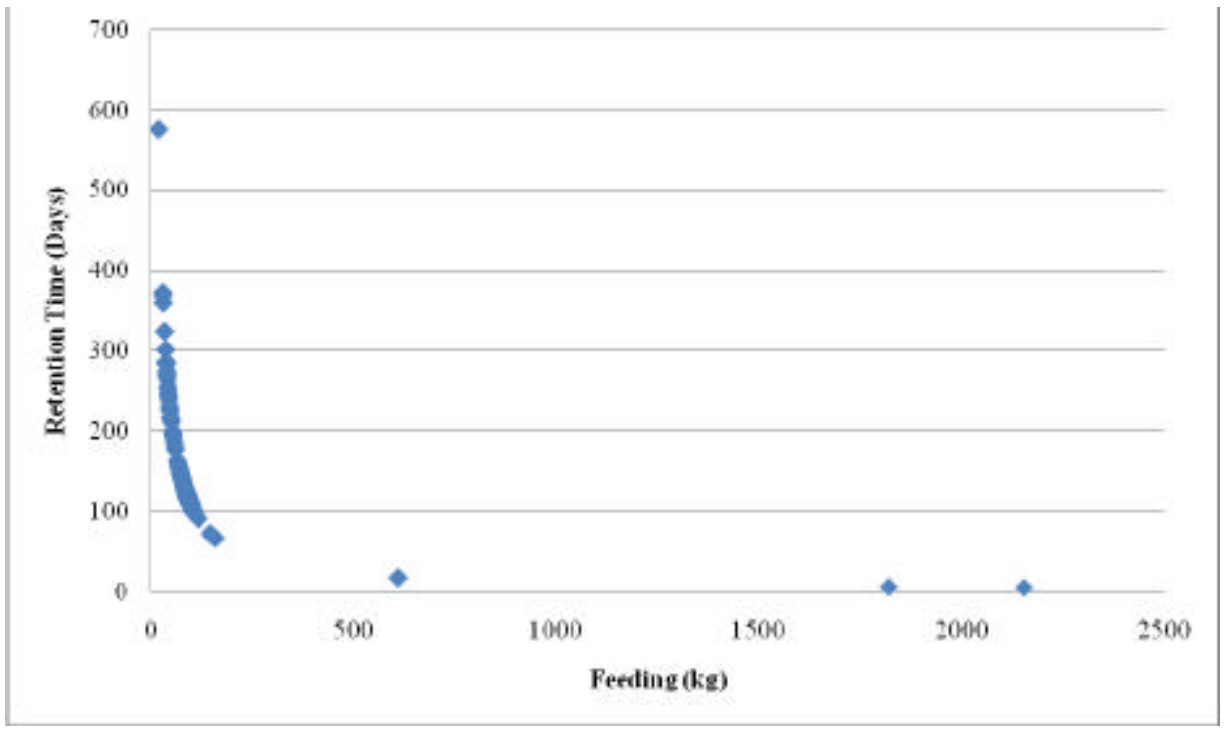

Fig. 4. Feeding and the retention time

Figure 4 indicates that the retention time of the biodigester was totally dependent upon the amount of feedstock added into the biodigester. The increase in the volume of the feeding materials the retention time decreased. The initial retention time of 213 days was in the beginning of the operation which decreased gradually as the feeding was increased.

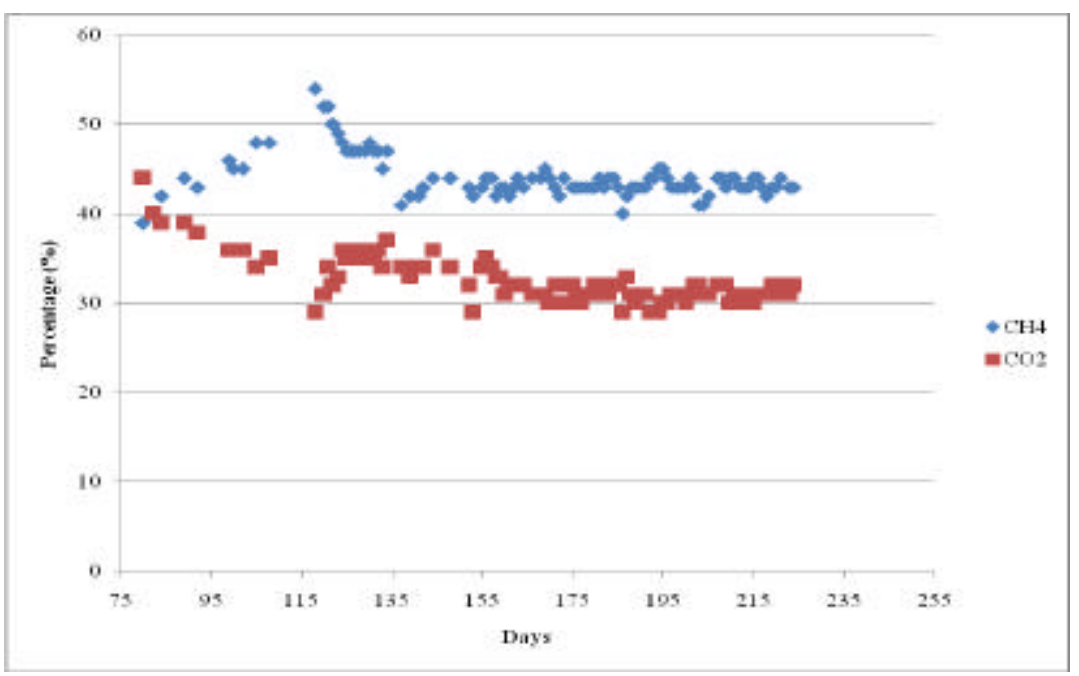

Fig. 5. Gas composition 
Figure 5 showed the percentage composition of methane $\left(\mathrm{CH}_{4}\right)$ and carbon-dioxide $\left(\mathrm{CO}_{2}\right)$ produced from the process. Though, initially percentage composition of both the gases were quite similar with the stabilization of biodigestion process, there was

\section{Analysis of pathogen}

Table 1. Laboratory test of the pathogens

\begin{tabular}{l|l|l|l|l|l|l}
\hline \multirow{2}{*}{\multicolumn{1}{c|}{ Name of the pathogens }} & \multicolumn{5}{c}{ Apsult } \\
\cline { 2 - 7 } & \multicolumn{2}{c}{ April } & \multicolumn{3}{c}{ May } \\
\hline Samples & Inlet & Outlet I & Outlet II & Inlet & Outlet I & Outlet II \\
Ascaris lubricoid & Fail & Fail & Fail & Fail & Fail & Fail \\
E.coli & Fail & Fail & Pass & Pass & Fail & Pass \\
Klebsiella spp. & Fail & Fail & Fail & Fail & Fail & Fail \\
Mycobacterium tuberculosis & Fail & Fail & Fail & Pass & Fail & Fail \\
Pseudomonas aeruginosa & Fail & Fail & Fail & Fail & Fail & Fail \\
Salmonella paratyphi & Fail & Fail & Fail & Fail & Fail & Fail \\
Salmonella typhi & Fail & Fail & Fail & Fail & Fail & Fail \\
Staphylococcus aureus & Fail & Fail & Fail & Fail & Fail & Fail \\
Staphylococcus epidermidis & Pass & Fail & Fail & Fail & Fail & Fail \\
Trichomonas & Fail & Fail & Fail & Fail & Fail & Fail \\
Yersinia enterocolitica & Fail & Fail & Fail & Fail & Fail & Fail
\end{tabular}

Table 1 revealed the result of pathogen analysis of the slurry which showed that most of the pathogens were not found to be present in the slurry. The high retention time of the biodigester could be a reason for is result.

Reduction in GHGs emission and global warming Consumption of fossil fuels, firewood and other gradual increase in the production of $\mathrm{CH}_{4}$ and decrease in the production of $\mathrm{CO}_{2}$. The maximum percentage of $\mathrm{CH} 4$ was found to be $54 \%$ and the minimum $\mathrm{CO} 2$ percentage recorded was $29 \%$. fuels emit gases like $\mathrm{CO}_{2}$ and $\mathrm{CH}_{4}$ causing the green house effect on earth. Use of biogas instead could prevent GHG emission contributing to both environmental and financial benefits. Table 2 depicted the annual reduction of $\mathrm{CO} 2$ emission from the operation of biodigester in this research set-up.

Table 2. $\mathrm{CO}_{2}$ equivalent calculation of the biodigestion plant

\begin{tabular}{l|l|l}
\hline \multicolumn{2}{l}{ For Calculation of $\mathrm{CO}_{2}$ equivalent } & $\mathrm{kg}$ \\
\hline Weight of mixed biodegredables & 94.50 & $\mathrm{~kg}$ of $\mathrm{CO}_{2}$ equivalent \\
Conversion factor & 2.20 & Tonnes of $\mathrm{CO}_{2}$ equivalent \\
Total $\mathrm{CO}_{2}$ equivalent & 0.21 & Tonnes of $\mathrm{CO}_{2}$ equivalent \\
Total $\mathrm{CO}_{2}$ equivalent/ per annum & 75.88 & USD \\
Rate of per tonnes of $\mathrm{CO}_{2}$ equivalent & 7 & USD per annum \\
Total cost saving & 531.1845 & \\
\hline
\end{tabular}

\section{Financial analysis}

Financial analysis identifies all the cost involved and the return from the activities in either financial, social

or any other term. If the benefit of the activity exceeds the cost of the investment then the project is considered viable. 
Nimesh Dhakal/Waste to Energy: Management.

Table 3. Calculation of the financial benefits from the average data

\begin{tabular}{|c|c|c|}
\hline \multicolumn{3}{|c|}{ Calculation with the average gas consumption data } \\
\hline Contractor fees/charges & 400000 & $\begin{array}{l}\text { Unit } \\
\text { NRs. }\end{array}$ \\
\hline Gas output per day & 5.78 & $\mathrm{~m}^{3} /$ day \\
\hline Gas output per month & 173.25 & $\mathrm{~m}^{3} / \mathrm{month}$ \\
\hline Percentage of Methane & 0.46 & $\%$ \\
\hline Total amount of methane content/day & 2.66 & $\mathrm{~m}^{3} /$ day \\
\hline Total amount of methane content/month & 79.70 & $\mathrm{~m}^{3} / \mathrm{month}$ \\
\hline One LPG cylinder contains & 14.20 & $\mathrm{Kg}$ \\
\hline Total LPG cylinder equivalent/month & 4.01 & \\
\hline Cost of gas per cylinder & 1500.00 & NRs \\
\hline Monthly saving & 6010.80 & NRs \\
\hline Yearly saving & 72129.59 & NRs \\
\hline Payback period & 5.5 & Years \\
\hline
\end{tabular}

Table 3 revealed that the payback period of the installed biodigester was 5.5 years. However, operation and maintenance cost of the biodigester was not included in the cost.

This study has elaborated the anaerobic digestion technology, as an alternative for the disposal of the biodegradable health care waste. Anaerobic digestion is a sustainable way of managing waste as it has technically been proven to be successful in treating the organic wastes and resulting in biogas and bio slurry.

Composition of methane in the biogas produced from biodegradable healthcare waste was $44 \%$ on an average, which was lower than $50-70 \%$ methane in biogas in general. (Karki et al. 2009). In this case, mostly the canteen waste, the left over food materials and the pathological waste were fed into the digester, which might be the reason for the lower methane content. Despite the fact, the technology was appropriate for the disposal of the biodegradable health care waste generated.

Initially the $\mathrm{pH}$ was in range of 5.5 which indicated the presence of acidogenesis stage. The initial period of operation of biodigester was acidogenesis (Chattwal 1998). However, the $\mathrm{pH}$ gradually increased and remained stable at the optimal range of 6-7 during the study period thus resulting in increase of gas production and pressure inside the dome. It was observed that in the TED model, the acidogenesis process occurred to some extent in the inlet as the waste remained in the inlet for few days before entering the digester. More detailed research is required to identify the extent.

No significant relationship could not be derived between temperature and gas production from this study. Various literature reviews, though, suggested the relationship between temperature and gas production being directly proportional. The gas production decreased in the cold season with the decrease in microbial activities (Karki et al. 2009). During this study, the temperature inside the dome was quite stable with no abrupt changes. This might be due to the insulation provided to the biodigester and the lower calibration and the standard of the temperature censor installed in the biodigester. However, this could be a topic for further research.

Slurry obtained from the study was analyzed for the presence of dreadful pathogens generated from the health care setting. No other harmful pathogens were identified except E.coli. Different studies in the slurry from biodigester showed the presence of Mycobacterium (Slana 2011). This study too focused on the presence of Mycobacterium species. Though it was identified in one instance in a sample from the inlet, its presence was nil in the sample from the outlet. 
This may be due to the longer retention time. The bio slurry thus obtained was free from pathogens and hence could be used as fertilizer.

Thus, this study successfully proved the anaerobic digestion technology as a safe alternative for the treatment of biodegradable health care waste.

\section{Acknowledgements}

The authors would like to express their grateful thanks to Central Department of Environmental Science, Tribhuvan University (CDES/TU) for allowing Nimesh Dhakal to carry out this research. Similarly, we sincerely thank Alternative Energy Promotion Center of the Ministry of Environment, Science and Technology (MoEST), Government of Nepal for the financial support to carry out this dissertation research work as well as to Bir Hospital for providing the space and Health Care Foundation Nepal (HECAF) for facilitating the study.

Thanks also go to Ms. Ruth Stringer of Health Care without Harm (HCWH) for the technical guidance and Prof. Dr. Jagganath Shrestha and Center for Energy studies IOE/TU for providing the equipments and guidance required for the study. Last but not the least, we would like to express our gratitude to Ms. Isha Sharma, Biogas Expert for providing invaluable comments and suggestions to finalize this paper.

\section{References}

BSP.2007. BSP year book 2007. Biogas Support Programme, Lalitpur, Nepal.

Chhatwal, G.R. 1998. Textbook of Biotechnology. Anmol Publication Pvt. Ltd. New Delhi.
CMS.1996. Biogas technology: A training manual for extension, Food and Agriculture Organization of the United Nations. Support for Development of National Biogas Programmes (FAO/TCP/Nep)

IPCC. 1996, Guidelines for National Greenhouse Gas Inventories, Reporting Instruction, Workbook and Reference Manual

Karki, A.B.2000. Training manual in biogas technology for the trainers of junior biogas technology. Biogas Support Programme-Nepal.

Karki, A.B, J.N. Shrestha, S. Bajgain and I. Sharma. 2009. "BIOGAS-As Renewable Source of Energy in Nepal: Theory and Development". Second Edition, BSPNepal' July.

MoH. 2003. Assessment of Present State and Establishment of Framework Strategy and Action Plan for Improvement, Ministry of Health, Government of Nepal, Kathmandu, Nepal. 16 pp.

Pruess, A., E. Giroult and P. Rushbrook.1999. Safe management of wastes from healthcare activities. WHO, Geneva. 380 pp.

Slana, I, R. Pribylova, A. Kralova and I. Pavlik. 2011, Persistence of Mycobacterium avium subsp. paratuberculosis at a Farm-Scale Biogas Plant Supplied with Manure from ParatuberculosisAffected Dairy Cattle, Applied and Environmental Microbiology 7(9): 3115-3119.

UNEP. 2001. Nepal: State of the Environment: 2001. United Nations Environment Programme (UNEP), in collaboration with Ministry of Environment, Government of Nepal.

Yashoda Sustainable Development (P) Ltd. 2008. Study and installation of vegetable and fruit waste biogas plant in Kathmandu Valley. A final report submitted to the then Ministry of Environment, Science and Technology, Alternative Energy Promotion Center, Khumaltar, Lalitpur, Nepal. 